\title{
Patient Rights in Health Services During the Covid 19 Pandemic
}

\author{
David Eka Prasetya ${ }^{1}$, Azis Budianto ${ }^{2}$ \\ \{oryzagrass@gmail.com ${ }^{1}$, azis_budianto@borobudur.ac.id $\left.{ }^{2}\right\}$ \\ Universitas Borobudur, Jakarta, Indonesia ${ }^{1,2}$
}

\begin{abstract}
This study analyzes the rights of patients in health services during the Covid 19 pandemic. By using a normative juridical approach and literature studies data collection, as well as being analyzed descriptively, it is found that normatively the rights of patients to receive health services are protected by law. Based on the data analysis, there are exceptions to fulfill patients' rights during a medical emergency. A constructive implementation of socialization is needed to the community so that there are no misunderstandings in health services to patients amid the Covid 19 Pandemic.
\end{abstract}

Keywords: Patient Rights; Health Services; Covid 19 Pandemic

\section{Introduction}

Health development is one of the elements of general welfare that must be realized by the government following Indonesian ideals as referred to in the 1945 Constitution,[1] to be specific to secure the whole Indonesian country and the whole country of Indonesia, to advance public government assistance, teach the country's life, and take an interest in doing world request dependent on autonomy, everlasting harmony, and civil rights.

As a general rule, wellbeing administrations are known to have specialist co-ops, for this situation, specialists, and the individuals who get administrations or complete wellbeing endeavors are patients. It has been known for quite a while for the trust relationship presence called a restorative exchange. The exchange is a corresponding relationship that is produced through correspondence, though restorative is something that contains components or treatment. Thus, juridical remedial exchanges are lawful connections among specialists and patients in proficient clinical benefits dependent on capabilities that follow specific aptitude and abilities in the field of medication where the administrations gave are giving help or help dependent on the patient's confidence in the specialist.

It is because health is a human right, and its fulfillment is one of the absolute requirements to achieve public welfare following the ideals of the Indonesian people as stated in the constitution of this country. As part of human rights, health needs to be protected by law. Thus, was born what we know as the law of health. Health law is all provisions or statutory regulations in the health sector that regulate the rights and obligations of the community as recipients of health services along with health workers and health facilities as providers of health services. 
Indonesia is also one of the countries affected by exposure to this virus according to the latest data from the National Disaster Management Agency (BNPB), the number of COVID19 cases in the country has reached 1,894,025 cases, 1,735,144 cases of which have been declared cured and 52,566 die cases. In terms of numbers, additions continue to occur every day, even when compared to the number of cases in June 2020, an increase of up to 5000\%.[2] The presence of the Health Law in a pandemic condition is crucial in protecting the rights of every citizen. Both in their capacity as patients or even as medical personnel. Based on the description above, it is interesting to discuss the role of Health Law, especially Patient Rights in the State of the COVID-19 Pandemic.

\section{Method}

The research method used is normative legal research. This research is performed by examining materials or secondary data so it can also be referred to as library law research. Secondary legal data is divided into primary legal materials, secondary legal materials, and tertiary legal materials. Legal materials that are authoritative, meaning they have authority.[3] Essential legitimate materials are comprise of enactment, official records, or minutes in the creation of enactment and judges' choices. The auxiliary materials are for the most part distributions on the law which are not official records. Optional lawful materials are fundamentally course readings because textbooks contain the basic principles of legal science and classical views of scholars who have high qualifications. Tertiary legal materials are nonlegal materials, such as journals and medical books, meant to explain primary and secondary legal materials.

\section{Discussion}

Patients are people who need health services. Furthermore, the rights and obligations of patients are stated in Law No. 36 of 2009 concerning Health,[4] one of which is in Article 5 section (3) which peruses: Everyone has the privilege to freely and mindfully decide the wellbeing administrations required for themselves. Different laws and guidelines that control pandemics and patient freedoms are Article 56. Article 2 expresses that the option to acknowledge or dismiss as alluded to in passage (1), doesn't make a difference to Patients with illnesses whose infections can immediately spread to the more extensive local area..

Looking at the provisions of paragraph (2) letter a, we can see that patients in this case who are exposed to the COVID-19 virus basically do not have the right to refuse medical services/actions. In reality, it is a pity that the public doesn't understand this. Many patients refuse to be treated or undergo a further examination that causes potential transmission also increases, especially to people in close contact with these patients, such as their own families.

But on the other hand, hospitals, especially medical personnel on duty, are not brave enough to implement these provisions strictly due to the principle of autonomy in the ethics of health services where patients have the right to determine their destiny and lack of support from the government. So far, there has not been much socialization regarding the exception to this right, so patients still assume that the decision to be treated or not is entirely in their hands. As a fellow medical worker, the author understands how difficult it is to deal with patients like this, especially their families. It doesn't just happen in one or two hospitals, one or two cities, it is even happening in almost all parts of Indonesia. 
The execution of the wellbeing administrations includes patients as gatherings who need wellbeing administrations, and wellbeing laborers as gatherings who offer their types of assistance with regards to recuperating patients. During the Covid-19 pandemic, the circumstance was unique in relation to the period before Covid-19. Some non-Covid-19 patients were impacted by the new framework during the pandemic to shield the interests of patients from the effect on wellbeing administrations of medical services suppliers during the Covid-19 pandemic, by alluding to Law Number 36 of 2009 concerning Health which directs legitimate security as a defender, or basic freedoms, and commitments, are managed in Articles 4, 5, 6, 7 and 8 while commitments are controlled in Articles 9, 10, 11, 12 and 13. [4]

During the Covid-19 pandemic season, each understanding should reserve the option to a solid climate as expressed in Article 6 of Law Number 36 of 2009 concerning Health, specifically a climate loaded up with individuals who submit to wellbeing conventions to keep away from the spread of the Covid-19 infection chain, so the current one of commitment is consequently should have been improved, in particular the commitment of each tolerant and wellbeing specialist co-op to consent to wellbeing conventions. By and large, Law Number 36 of 2009 concerning Health in 3 articles, in particular articles 56, 57, and 58, directs lawful security for patients.[4] As indicated by Philipus M. Hadjon, legitimate security is assembled into 2 sections, in particular preventive lawful assurance remembering lawful insurance from the public authority as avoidance for advance of infringement. Furthermore, abusive lawful security, to be specific close assurance as approvals given to violators when there has been an infringement or debate in fines, detainment, and extra punishments.

Legitimate insurance for patients in Article 56 of Law No. 36 of 2009 concerning Health can be sorted as preventive lawful insurance or as anticipation ahead of law infringement, lawful assurance for the patient is completed through giving informed assent.[5] Informed assent comes from two words, "informed" and "assent." "Informed" signifies data about something, while "assent" signifies assent so the significance of informed assent is the assent of the patient or the patient's family can be addressed on the clinical activity taken by specialists as wellbeing laborers who have some familiarity with about recuperating the patient's condition concerning doing clinical treatment to the patient,[6] It is the place where after the specialist clarifies the medical issues experienced by the patient and how to deal with these issues as clinical activities pointed toward giving recuperating to the patient, yet prior to doing the clinical therapy, the patient or his family can be addressed by the option to have the decision of tolerating or dismissing, this right can be applied to each persistent, aside from patients who host irresistible infections to huge gatherings, oblivious patients or patients who have serious mental problems.

The nitty gritty execution of informed assent is directed in Law No. 29 of 2004 concerning Medical Practice in Article 45 section (4), where the assent made by the patient should be possible either orally or recorded as a hard copy. Informed assent is expressed by the patient orally if the dangers presented by clinical activity by the specialist don't significantly affect the patient, for example, ordinary clinical check-ups or organization of medications for treatment. Then again, composed endorsement is completed on the grounds that clinical activities taken by specialists against patients have a huge enough danger that it requires composed proof that finished with endorsement signature by the patient if he concurs as expressed in Article 45 section (5) of Law Number 29 of 2004 concerning Medical practice.[7]

To understand the most significant level of wellbeing for the local area, an incorporated and extensive wellbeing exertion is completed in individual wellbeing endeavors and general wellbeing endeavors. Wellbeing endeavors are coordinated as exercises with promotive, preventive, remedial, and rehabilitative methodologies in an incorporated, extensive, and 
maintainable way. Wellbeing endeavors are performed to understand the most significant level of wellbeing for people or society. The execution of wellbeing administrations is acted in a capable, protected, quality, fair, and non-oppressive way. So that matters identifying with Patient Protection in Health Services are as per the following:

a. Everyone has the privilege to acknowledge or dismiss part or all of the alleviation estimates that will be given to him in the wake of getting and completely understanding the data with respect to the activity.

b. The right to accept or reject the above does not apply to:

1. a patient with a disease whose disease can quickly spread to the broader community;

2. the state of an unconscious person; or

3. severe mental disorders.

c. Everyone has the option to the classification of his medical issue that has been revealed to the wellbeing specialist organization.

d. Everyone has the privilege to guarantee pay for an individual, wellbeing specialist, or potentially wellbeing supplier who makes a misfortune due a mistake or carelessness in the wellbeing administration they get.

The rights of these patients are worth fighting for in health services. During the Covid-19 Pandemic, every patient has the right to receive the same health services during the prepandemic situation. The right to obtain health services, whether preventive, curative, and rehabilitative, needs to be implemented in an integrated, comprehensive, and sustainable manner so that patients are maintained and get their rights.

\section{Conclusion}

The Government responsibilities in the Implementation of Health Efforts Based on Law Number 36 of 2009 is to form extraordinary policies in the context of preventing, suppressing, and controlling the spread of Covid-19 and the Government, local state run administrations, and the local area are liable for the accessibility of assets, offices, and execute exhaustive and practical wellbeing administrations in misfortunes. Lawful security for patients in acquiring wellbeing administrations during the Covid-19 pandemic dependent on the 2009 Law of the Republic of Indonesia concerning Health is to ensure the implementation of patient rights and professional medical treatment. The government needs to guarantee the fulfillment of this patient's rights to the community as well as the realization of the implementation of sanctions that may arise if this exception is violated so that hospitals and medical personnel can be bolder to implement these provisions strictly. Thus, the transmission of the COVID-19 virus can be prevented and the increase of COVID-19 sufferers can be suppressed.

\section{Reference}

[1] Republik Indonesia, "Undang Undang Dasar Negara Republik Indonesia Tahun 1945, Pasal 1 angka (3)." Sekretariat Negara, Jakarta, 1945.

[2] A. S. Rahayu, "Lockdown Versi Indonesia," Arsip Publ. Ilm. Biro Adm. Akad., 2020.

[3] D. L. Sonata, "METODE PENELITIAN HUKUM NORMATIF DAN EMPIRIS: KARAKTERISTIK KHAS DARI METODE MENELITI HUKUM," FIAT JUSTISIAJurnal Ilmu Huk., 2015, doi: 10.25041/fiatjustisia.v8no1.283.

[4] Sekretariat Negara, "Undang-Undang Nomor 36 Tahun 2009 tentang Kesehatan." 
Jakarta, 2009.

[5] A. Y. Ramadianto, "Informed Consent Sebagai Persetujuan Dalam Kontrak Terapeutik Antara Dokter Dan Pasien," J. Simbur Cahaya, vol. 24, no. 1, 2017.

[6] C. Paules, H. Marston, and A. Fauci, "Coronavirus Infections-More Than Just the Common Cold," JAMA Netw., vol. 232, no. 8, 2020.

[7] Sekretariat Negara, "Undang-Undang Nomor 29 Tahun 2004 tentang Praktik Kedokteran.” Jakarta, 2004. 